\title{
Positive Renal Response to Intravenous Acetazolamide in Patients with Carbonic Anhydrase II Deficiency
}

\author{
WILLIAM S. SLY, MICHAEL P. WHYTE, THEODORE KRUPIN, AND VASANTHA SUNDARAM \\ E.A. Doisy Department of Biochemistry [W.S.S., V.S.], St. Louis University School of Medicine, St. Louis, \\ Missouri 63104; Division of Bone and Mineral Metabolism [M.P.W.], Departments of Medicine and Pediatrics, \\ Washington University School of Medicine, St. Louis, Missouri 63110; and Scheie Eye Institute [T.K.] \\ Department of Ophthalmology, University of Pennsylvania School of Medicine,
}

Philadelphia, Pennsylvania 19104

\begin{abstract}
Carbonic anhydrase II (CA II) is the only soluble isozyme of $\mathrm{CA}$ which is known to be expressed in kidney. We recently identified a deficiency of this enzyme as the basis for the autosomal recessive syndrome of osteopetrosis with renal tubular acidosis and cerebral calcification. In order to explore the physiological importance of CA II in the kidney, we studied the renal response to intravenously infused acetazolamide in two CA II-deficient patients and two control subjects. Following acetazolamide infusion, the CA II-deficient patients exhibited a prompt rise in urinary $\mathrm{pH}$ and $\mathrm{HCO}_{3}{ }^{-}$excretion similar to the response seen in control subjects. These findings indicate that CA II-deficient patients, who lack detectable CA II in their erythrocytes, still expressed an acetazolamide-inhibitable CA activity in their kidneys. These results can be explained in three ways: 1) the CA II deficiency which is profound in the erythrocytes of these patients may not be expressed in their kidney. 2) An acetazolamide-sensitive CA other than CA II, such as CA I and CA III, which is not normally expressed in kidney, is expressed in kidneys of CA II-deficient patients. 3) The CA II deficiency is expressed in kidney in these patients but the acetazolamide response is due to inhibition of the luminal, membranebound $\mathrm{CA}$ which is the product of a different gene and unaffected by the CA II deficiency mutation. We favor the third possibility. On this basis, we suggest that patients with CA II deficiency provide an experiment of nature which complements existing pharmacological evidence that distinguishes the contributions of CA II and the membranebound $\mathrm{CA}$ to $\mathrm{HCO}_{3}{ }^{-}$reclamation by the human kidney. A model to explain their roles in proximal and distal acidification is presented. (Pediatr Res 19: 1033-1036, 1985)
\end{abstract}

\section{Abbreviations}

CA, carbonic anhydrase

RTA, renal tubular acidosis

CA II deficiency was recently identified as the primary defect in the autosomal recessive syndrome of osteopetrosis with RTA

Received April 8, 1985; accepted May 24, 1985.

Correspondence William S. Sly, M.D., E.A. Doisy Department of Biochemistry, St. Louis University School of Medicine, 1402 South Grand Boulevard, St. Louis, MO 63104.

Supported by Research Grant RR-00036 from the General Clinical Research Center Branch, Division of Research Facilities and Resources, National Institutes of Health, support from the National Foundation-March of Dimes, and NIH Research Grants GM 31988 and AI/GM 20610. and cerebral calcification (1). This CA isozyme, which was formerly called CA C, is normally widely distributed in man and has been identified (immunologically or by purification) in erythrocytes, brain, kidney, eye, cartilage, liver, lung, skeletal muscle, pancreas, gastric mucosa, and anterior pituitary body $(2,3)$. The other $\mathrm{CA}$ isozymes, whose activities toward $\mathrm{CO}_{2}$ and $\mathrm{HCO}_{3}{ }^{-}$are lower than those of CA II in the order of CA II $>$ CA IV $>C A$ I>CA III (4-6), appear to have a more limited tissue distribution. CA I is found primarily in erythrocytes and CA III mainly in skeletal muscle (5). CA IV differs from CA I, CA II, and CA III, the soluble cytosolic carbonic anhydrases, in being a membranebound glycoprotein and is found in the lung (4). Identification of a quantitative defect in CA II in patients with this new inborn error of metabolism provides us with a unique opportunity to assess the importance and function of CA II in humans.

We report herein studies of the renal response to intravenously infused acetazolamide (a CA inhibitor) in CA II-deficient patients. The renal response to infused acetazolamide in these patients is of great interest since CA II is the only soluble CA isozyme identified in the kidney (7-9), and its absence apparently is responsible for the mixed or hybrid-type RTA in CA IIdeficient patients (10-15). However, there have been recent reports of a less well-characterized, membrane-bound luminal CA in the brush border of the proximal tubule of the kidney (16, 17). The luminal CA appears to play an important role in the reclamation of filtered $\mathrm{HCO}_{3}{ }^{-}$and is known to be sensitive to inhibition by acetazolamide $(18,19)$. If the membrane-bound, luminal CA is the product of a different gene than CA II, and if this gene is expressed normally in CA II-deficient patients, infused acetazolamide would be expected to inhibit the luminal $\mathrm{CA}$ and produce an $\mathrm{HCO}_{3}{ }^{-}$diuresis in CA II-deficient patients. In the experiment described below, we compare the renal response to intravenous infusion of acetazolamide in two of the patients with CA II deficiency that we described previously (1, 11 ) with the responses of two control subjects.

\section{METHODS}

Experimental subjects. Two sisters (25 and $32 \mathrm{yr}$ of age) homozygous for CA II deficiency (1) and two healthy men (22 and $24 \mathrm{yr}$ of age) were studied. Urine acidification has been assessed previously in the CA II-deficient sisters following the oral administration of $1.5 \mathrm{~g}$ of ammonium chloride four times daily for 3 days (11). The $\mathrm{pH}$ of their urine collected under oil (Radiometer $\mathrm{pH}$ meter) was 5.58 and 5.40 while the plasma pH was 7.17 and 7.12 , respectively. These findings demonstrated a distal RTA. Although a low Tm for $\mathrm{HCO}_{3}{ }^{-}$has been documented in other patients with this syndrome, studies to demonstrate this abnormality in these two patients were not successfully completed (11). 
None of the subjects was taking medication. The men were of comparable weights to the patients. Following informed consent, an aliquot was aspirated immediately from a timed urine collection into a $10-\mathrm{ml}$ syringe and heparinized venous blood was collected without stasis into a $3-\mathrm{ml}$ syringe. Syringes were immediately placed on ice. Each subject then received a single intravenous bolus of $125 \mathrm{mg}$ of acetazolamide (Diamox, Lederle Laboratories, Division of American Cynamid Co., Pearl River, NY) dissolved in $1.25 \mathrm{ml}$ normal saline, and the same studies were repeated at intervals during the subsequent 4-h period.

Biochemical studies were performed in the Clinical Chemistry Laboratory, Barnes Hospital, St. Louis, MO. Plasma and urine electrolytes $\left(\mathrm{Na}^{+}, \mathrm{Cl}^{-}, \mathrm{K}^{+}\right.$, total $\left.\mathrm{CO}_{2}\right)$ were assayed with an Astra8 automated analyzer (Beckman Instruments, Louisville, $\mathrm{KY}$ ). Urine $\mathrm{pH}$ was determined with a Radiometer $\mathrm{pH}$ meter.

\section{RESULTS}

Results are summarized in Tables 1 and 2. Basal venous $\mathrm{pH}$ and measured total $\mathrm{CO}_{2}$ values in the patients with $\mathrm{CA}$ II deficiency (Table 1) were in keeping with their previously documented RTA $(1,11)$. Intravenous infusion of acetazolamide was well tolerated, both in patients and controls and was followed by a slight but progressive decrease in venous $\mathrm{pH}$. Since the plasma $\mathrm{HCO}_{3}{ }^{-}$did not decrease, the acute decrease in $\mathrm{pH}$ following acetazolamide infusion must be entirely due to an increase in $\mathrm{pCO}_{2}$. From data shown in Table 2 , it is clear that both the patients and controls demonstrated an abrupt increase in urine $\mathrm{pH}$ which was associated with increased urinary $\mathrm{HCO}_{3}^{-}$excretion. Elevation of $\mathrm{pH}$ persisted even longer in patients than in controls. Urinary $\mathrm{Na}^{+} /$creatinine and $\mathrm{K}^{+} /$creatinine ratios both increased with the bicarbonaturia. However, the $\mathrm{Cl}^{-} /$creatinine ratio did not show a corresponding increase.

\section{DISCUSSION}

Two principal types of osteopetrosis have been described in man $(20,21)$. One is the dominantly inherited, relatively benign condition which is often detected radiologically in asymptomatic adults. A second type is the recessive, lethal, malignant form of osteopetrosis. This form is usually present at birth, becomes symptomatic early in infancy, and leads to death by early childhood from infection or bleeding. Since 1972, a number of families such as the one studied here have been reported with a recessively inherited syndrome of osteopetrosis with RTA and cerebral calcification $(11-15)$ that is compatible with long survival. We recently presented evidence from studies in one kindred that a deficiency of CA II is the basic defect in this

Table 1. Response of venous $\mathrm{pH}$ and total $\mathrm{CO}_{2}$ to intravenous infusion of acetazolamide in carbonic anhydrase II-deficient patients and controls

\begin{tabular}{lllll}
\hline & \multicolumn{4}{c}{ Time After Acetazolamide } \\
\cline { 4 - 5 } & Baseline & 1 Hour & 2 Hours & 4 Hours \\
\hline $\mathrm{pH}$ & & & & \\
$\mathrm{P} 1$ & 7.22 & 7.20 & 7.18 & 7.17 \\
$\mathrm{P} 2$ & 7.23 & 7.22 & 7.20 & 7.19 \\
$\mathrm{C} 1$ & 7.34 & 7.32 & & 7.32 \\
$\mathrm{C} 2$ & 7.32 & 7.30 & & 7.28 \\
& & & & \\
Total CO (measured) & & & & \\
(mM) & & & & \\
$\mathrm{P} 1$ & 17 & 22 & 20 & 20 \\
$\mathrm{P} 2$ & 19 & 20 & 21 & 20 \\
$\mathrm{Cl}$ & 27 & 26 & & 26 \\
$\mathrm{C} 2$ & 28 & 30 & & 29 \\
\hline
\end{tabular}

* P1 and P2 are CA II-deficient patients III- 1 and III- 6 from the family we reported previously (1), and $\mathrm{C} 1$ and $\mathrm{C} 2$ are control subjects $\mathrm{BG}$ and PL.
Table 2. Response of urine $\mathrm{pH}$ and electrolytes to intravenous infusion of acetazolamide in carbonic anhydrase II-deficient patients and controls*

\begin{tabular}{|c|c|c|c|}
\hline & \multirow[b]{2}{*}{ Baseline } & \multicolumn{2}{|c|}{$\begin{array}{c}\text { Time after } \\
\text { acetazolamide }\end{array}$} \\
\hline & & $0-2 \mathbf{H}$ & $2-4 \mathrm{H}$ \\
\hline \multicolumn{4}{|l|}{$\mathrm{pH}$} \\
\hline $\mathrm{P} 1$ & 5.9 & 7.8 & 8.0 \\
\hline $\mathrm{P} 2$ & 5.4 & 7.7 & 8.1 \\
\hline $\mathrm{Cl}$ & 6.1 & 7.8 & 7.5 \\
\hline $\mathrm{C} 2$ & 6.7 & 7.7 & 7.3 \\
\hline \multicolumn{4}{|c|}{ Measured $\mathrm{HCO}_{3}^{-}(\mathrm{mM})$} \\
\hline P1 & $<5$ & $>40$ & \\
\hline $\mathrm{P} 2$ & $<5$ & $>40$ & \\
\hline $\mathrm{Cl}$ & 1.7 & $>40$ & 60 \\
\hline $\mathrm{C} 2$ & 5.2 & $>40$ & 41 \\
\hline \multicolumn{4}{|l|}{$\mathrm{Na}^{+}$} \\
\hline P1 & 94 & 299 & 266 \\
\hline $\mathrm{P} 2$ & 55 & 248 & 237 \\
\hline $\mathrm{Cl}$ & 107 & 324 & 223 \\
\hline $\mathrm{C} 2$ & 213 & 397 & 327 \\
\hline \multicolumn{4}{|l|}{$\mathrm{K}^{+}$} \\
\hline P1 & 32 & 104 & 164 \\
\hline $\mathrm{P} 2$ & 37 & 120 & 136 \\
\hline $\mathrm{Cl}$ & 90 & 218 & 174 \\
\hline $\mathrm{C} 2$ & 93 & 149 & 127 \\
\hline \multicolumn{4}{|l|}{$\mathrm{Cl}^{-}$} \\
\hline P1 & 116 & 129 & 96 \\
\hline $\mathrm{P} 2$ & 80 & 135 & 84 \\
\hline $\mathrm{Cl}$ & 152 & 188 & 108 \\
\hline $\mathrm{C} 2$ & 283 & 254 & 177 \\
\hline
\end{tabular}

* $\mathrm{Na}^{+}, \mathrm{K}^{+}$, and $\mathrm{Cl}^{-}$excretion are expressed as $\mathrm{mmol} / \mathrm{g}$ creatinine. $\mathrm{P} 1$ and $\mathrm{P} 2$ are CA II-deficient patients III-1 and III- 6 from the family we reported previously (1), and $\mathrm{C} 1$ and $\mathrm{C} 2$ are control subjects BG and PL.

syndrome. We have since extended this finding to many other similarly affected families $(22,30)$. The renal abnormalities in this syndrome are still incompletely understood. Most patients reported have a mixed or hybrid-type RTA (10-15). A proximal component was suggested by $\mathrm{HCO}_{3}^{-}$wasting at normal plasma concentrations (i.e. a low Tm for $\left.\mathrm{HCO}_{3}^{-}\right)(12-25)$. A distal defect, profound in some patients, was evident from their inadequate ability to acidify their urine, even while quite acidotic (13-15).

CA II is normally present in both proximal and distal tubules $(9,23)$. Lönnerholm (23) recently compared histochemical and immunohistochemical staining of human kidney preparations and confirmed the earlier findings of Spicer et al. (9) that the distal tubule and the collecting duct have a more intense immunohistochemical reaction for CA II than the moderate to light staining found in the cytoplasm of cells in the proximal tubule. Lönnerholm also found that the CA in the brush border of the proximal tubule (the luminal or membrane-bound CA) stains histochemically, but does not react with antisera to either CA II or CA I. Lack of cross-reactivity could result from failure of the histochemical reagents to get access to CA I or CA II in membranes. However, when this observation is taken together with the evidence that the luminal enzyme is an integral membrane glycoprotein and much larger than the soluble isozymes $(53 \mathrm{~K}$ versus $29 \mathrm{~K})(24)$, the more likely interpretation is that the luminal enzyme is immunologically distinct and the product of a different gene than that which specifies CA II.

We have no direct evidence on the status of CA II in the kidney of patients with the syndrome of osteopetrosis with RTA and cerebral calcification. Recent studies of CA activity in whole 


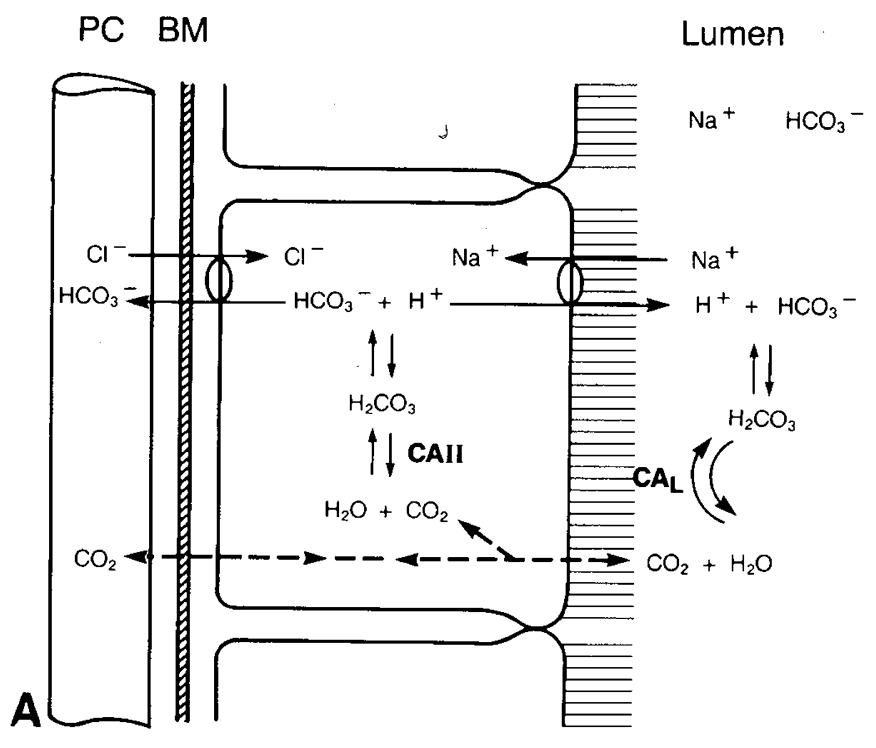

PC BM

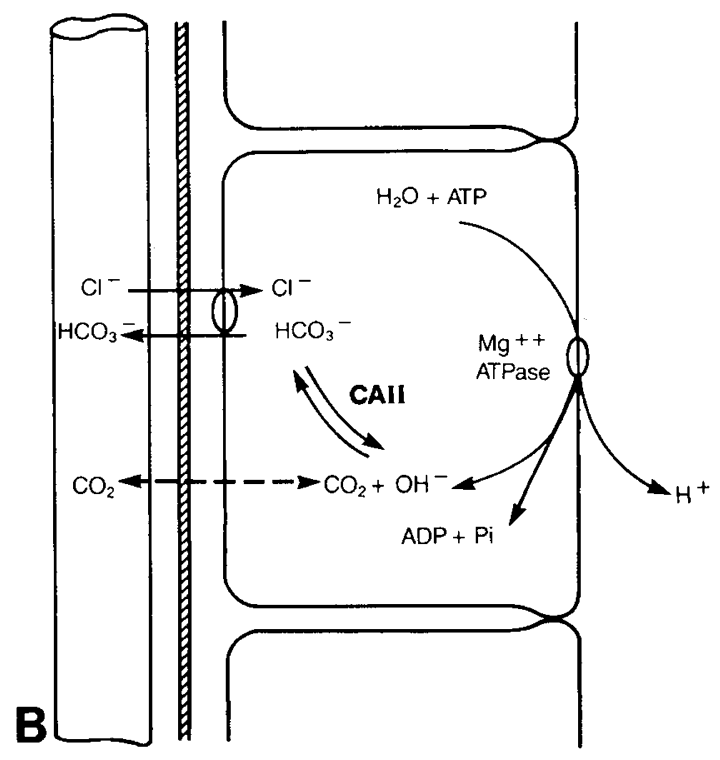

Fig. 1. $A$, proposed roles of carbonic anhydrases in bicarbonate reclamation in the proximal tubule. $\mathrm{Na}^{+}$and $\mathrm{HCO}_{3}{ }^{-}$enter the lumen of the proximal tubule. $\mathrm{H}^{+}$is secreted in exchange for $\mathrm{Na}^{+}$, and $\mathrm{H}^{+}$and $\mathrm{HCO}_{3}{ }^{-}$ are converted to $\mathrm{CO}_{2}$ and $\mathrm{H}_{2} \mathrm{O}$ in a reaction catalyzed by the luminal CA $\left(C A_{L}\right)$. We propose that this enzyme functions normally in CA IIdeficient patients, and its inhibition explains the positive response to acetazolamide. $\mathrm{CO}_{2}$ diffuses freely into the proximal tubular cell [and across the basement membrane $(B M)$ and into the peritubular capillary $(P C)$ ], and is exposed to cytosolic CA II which catalyzes its rehydration to form $\mathrm{HCO}_{3}{ }^{-}$and $\mathrm{H}^{+}$. The $\mathrm{HCO}_{3}{ }^{-}$is transported from the contraluminal surface of the proximal tubular cell (probably in exchange for $\mathrm{Cl}^{-}$) and the $\mathrm{H}^{+}$generated by CA II is secreted in exchange for $\mathrm{Na}^{+}$to initiate another cycle of $\mathrm{HCO}_{3}{ }^{-}$reabsorption. Loss of CA II-mediated regeneration of $\mathrm{H}^{+}$is suggested as the cause of $\mathrm{HCO}_{3}{ }^{-}$wasting in CA II-deficient patients. $B$, proposed role of $\mathrm{CA}$ II in distal urinary acidification. We propose that $\mathrm{H}^{+}$is secreted into the lumen by a proton = translocating $\mathrm{Mg}^{++}$ATPase, as in amphibians, which produces $\mathrm{OH}^{-}$in the cytosol. $\mathrm{CO}_{2}$ can condense with $\mathrm{OH}^{-}$to form $\mathrm{HCO}_{3}^{-}$in a CA II-catalyzed reaction, and $\mathrm{HCO}_{3}{ }^{-}$can be transported across the basement membrane and into the peritubular capillary. We suggest that failure to titrate the $\mathrm{OH}^{-}$limits the ability to secrete $\mathrm{H}^{+}$and acidify the urine appropriately in CA II-deficient patients. erythrocytes from the two patients described herein, using $a^{18} \mathrm{O}$ exchange method, demonstrated $55 \%$ of normal CA activity. This activity was attributed to the CA I isozyme, which is not diminished in these patients (22). These studies suggest that the CA II-deficient erythrocytes are not functionally impaired in $\mathrm{CO}_{2}$ transport in vivo. Thus, the RTA is more likely to be the direct result of a deficiency of the CA II isozymes in the kidneys than a secondary consequence of CA II deficiency in erythrocytes.

In Figure 1 we present a model which can explain both the renal abnormalities in CA II-deficient patients and their positive response to acetazolamide. In this model both the luminal (membrane-bound) $\mathrm{CA}$ and the soluble, cytosolic $\mathrm{CA}$ contribute to $\mathrm{HCO}_{3}{ }^{-}$reabsorption in the proximal tubule in normal subjects (Fig. 1 $A$ ). Studies with $\mathrm{CA}$ inhibitors proved that enzymatic conversion of $\mathrm{HCO}_{3}^{-}$to $\mathrm{CO}_{2}$ is normally crucial for $\mathrm{HCO}_{3}^{-}$ reabsorption by the proximal tubule (25). That the CAs act at different sites and in different ways was suggested by experiments of Lucci et al. (19). When the luminal enzyme was selectively inhibited, more than $80 \%$ of the $\mathrm{HCO}_{3}^{-}$reabsorption by proximal tubule was blocked $(18,19)$. Inhibition of the cytosolic enzyme, in addition, did not further inhibit $\mathrm{HCO}_{3}{ }^{-}$reabsorption, although it did reduce $\mathrm{H}^{+}$secretion into the proximal tubule (19). There is widespread agreement that $\mathrm{HCO}_{3}{ }^{-}$reabsorption depends on secretion of hydrogen ions (25-27), and that an acetazolamide-sensitive intracellular CA plays a role in generating $\mathrm{H}^{+}$for $\mathrm{HCO}_{3}{ }^{-}$reclamation $(19,16)$. Since CA II is the only soluble CA in kidney $(7-9,23,24)$, we attribute this function to CA II. We suggest that it is loss of the ability to regenerate $\mathrm{H}^{+}$ enzymatically which explains the impaired reabsorption of $\mathrm{HCO}_{3}{ }^{-}$in CA II-deficient patients. Such patients can waste up to $25 \%$ of the filtered load of $\mathrm{HCO}_{3}{ }^{-}$when their $\mathrm{HCO}_{3}{ }^{-}$concentrations are raised to normal levels by infusion (12-15). However, $\mathrm{HCO}_{3}{ }^{-}$wasting is not seen when patients are severely acidotic, suggesting that reabsorption of low filtered loads of $\mathrm{HCO}_{3}{ }^{-}$does not require CA II.

Most Ca II-deficient patients are unable to acidify their urine appropriately when acidotic, suggesting a role for CA II in distal acidification as well. Immunohistochemical evidence indicates that certain cells of the distal tubule and the collecting ducts of the human kidney are "CA rich" like their possible analogs in amphibians $(9,23)$. In the turtle bladder, these specialized cells secrete $\mathrm{H}^{+}$through a proton-translocating $\mathrm{Mg}^{++} \mathrm{ATPase}$, and are capable of generating a steep pH gradient $(28,29)$. The CA rich cells are sensitive to acetazolamide, possibly because CA is needed to titrate the $\mathrm{OH}^{-}$produced in the cytosol by the protontranslocating $\mathrm{Mg}^{++}$-ATPase. In the model presented (Fig. $1 B$ ), we suggest a similar role for CA II in the distal tubules and collecting ducts of the human kidney. Such a role for CA II could explain the distal defect reported in many CA II-deficient patients.

An experiment related to that reported herein was reported by Guibaud et al. (12) in 1972. When they observed a response to acetazolamide indicating an acetazolamide-sensitive CA in kidney in their patients with this syndrome, they concluded that CA deficiency must now be the basis of their osteopetrosis with RTA. These observations must now be reinterpreted. We recently collaborated with Professor Guibaud to measure CA II levels in erythrocytes from his patients and found in them the same profound deficiency of CA II (22) that we reported earlier (1) in the two sisters studies in this report. We propose that in his patients as in our patients, the bicarbonaturia following acetazolamide can be explained by inhibition of the luminal carbonic anhydrase which is not affected by the mutation which produces the CA II deficiency syndrome.

Acknowledgments. The authors are grateful to the nurses of the Adult Clinical Research Center, Washington University Medical Center, whose help made this study possible, to Drs. Bernard Becker and Lee Hamm, for helpful suggestions for the manuscript, and to Barbara Groneck for help in preparing the manuscript. 


\section{REFERENCES}

1. Sly WS, Hewett-Emmett D, Whyte MP, Yu Y-SL, Tashian RE 1983 Carbonic anhydrase II deficiency identified as the primary defect in the autosomal recessive syndrome of osteopetrosis with renal tubular acidosis and cerebral calcification. Proc Natl Acad Sci 80:2752-2756

2. Tashian RE 1977 Evolution and regulation of the carbonic anhydrase isozymes. In: Rattazzi MC, Scandalios JG, Whitt GS (eds) Isozymes: Current Topics in Biological and Medical Research, vol 2. Alan R Liss, New York, pp 2162

3. Tashian RE, Hewett-Emmett D, Goodman M 1983 On the evolution and genetics of carbonic anhydrase I, II, and III. In: Rattazzi MC, Scandalios JG, Whitt GS (eds) Isozymes: Current Topics in Biological and Medical Research, vol 7. Alan R Liss, New York, pp 79-100

4. Whitney PL, Brigge TV 1983 Membrane-associated carbonic anhydrase purified from bovine lung. J Biol Chem 257:12056-12059

5. Koester MK, Pullan LM, Noltmann EA 1979 the 5 p-nitrophenyl phosphatase activity of muscle carbonic anhydrase. Arch Biochem Biophys 211:632-642

6. Sanyal G, Swenson ER, Pessah NI, Maren TH 1982 The carbon dioxide hydration activity of skeletal muscle carbonic anhydrase. Inhibition of sulfonamides and anions. Mol Pharmacol 22:211-220

7. Wistrand PJ 1980 Human renal cytoplasmic carbonic anhydrase. Tissue levels and kinetic properties under near physiological conditions. Acta Physiol Scand 109:239-248

8. Dobyan DC, Bulger RE 1982 Renal carbonic anhydrase. Am J Physiol 243(4):PF311-24

9. Spicer SS, Sens MA, Tashian RE 1982 Immunocytochemical demonstration of carbonic anhydrase in human epithelial cells. J Histochem Cytochem 30:864-873

10. Sly WS, Lang R, Avioli L, Haddad J, Lubowitz H, McAlister W 1972 Recessive osteopetrosis: new clinical phenotype. Am J Hum Genet 24:34(abstr)

11. Whyte MP, Murphy WA, Fallon MD, Sly WS, Teitelbaum SL, McAlister WH, Avioli LV 1980 Osteopetrosis, renal tubular acidosis and basal ganglia calcification in three sisters. Am J Med 69:64-74

12. Guibaud P, Larbre F, Freycon MT, Genoud J 1972 Osteopetrosis and renal tubular acidosis. Two cases of this association in a sibship. Arch Franc Pediatr 29:269-286

13. Vainsel M, Fondu P, Cadranel S, Rosman C, Gepts W 1972 Osteopetrosis associated with proximal and distal tubular acidosis. Acta Paediatr Scand 61:429-434

14. Bourke E, Delaney VB, Mosawi M, Reavey P, Leston M 1981 Renal tubular acidosis and osteopetrosis in siblings. Nephron 28:268-272

15. Bregman H, Brown J, Rogers A, Bourke E 1982 Osteopetrosis with combined proximal and distal renal tubular acidosis. Am J Kidney Dist 2:357-362
16. Wistrand PJ 1979 Renal membrane-bound carbonic anhydrase. Purification and properties. Upsala J Med Sci Suppl 26:75(abstr)

17. Sanyal G, Pessah NI, Maren TH 1981 Kinetics and inhibition of membranebound carbonic anhydrase from canine renal cortex. Biochim Biophys Acta 657:128-137

18. Tinker JP, Coulson R, Weiner IM 1981 Dextran-bound inhibitors of carbonic anhydrase. J Pharmacol Exp Ther 218:600-607

19. Lucci MS, Tinker JP, Weiner IM, DuBose Jr. TD 1983 Function of proximal tubule carbonic anhydrase defined by selective inhibition. Am J Physiol 245:443-449

20. Johnston Jr CC, Lavy N, Lord T, Vellios F, Merritt AD, Deiss Jr WP 1968 Osteopetrosis. A clinical, genetic, metabolic, and morphologic study of the dominantly inherited, benign form. Medicine 47:149-167

21. Beighton P, Hamersma H, Cremin BJ 1979 Osteopetrosis in South Africa. The bengin, lethal and intermediate forms. S Afr Med J 55:659-665

22. Tashian RE, Hewett-Emmett D, Dodgson S, Forster RE, Sly WS 1984 The value of inherited deficiencies of human carbonic anhydrases in understanding their cellular roles. In: Tashian RE, Hewett-Emmett D (eds) Biology and Chemistry of the Carbonic Anhydrases. Ann NY Acad Sci 429:262-275

23. Lönnerholm F 1984 Histochemical locations of carbonic anhydrase in mammalian tissues. In: Tashian RE, Hewett-Emmett D (eds) Biology and Chemistry of the Carbonic Anhydrases. Ann NY Acad Sci 429:369-381

24. Wistrand PJ 1984 Properties of membrane bound carbonic anhydrase. In: Tashian RE, Hewett-Emmett D (eds) Biology and Chemistry of the Carbonic Anhydrases. Ann NY Acad Sci 429:195-206

25. Cogan MG, Maddox DA, Warnock DG, Lin ET, Rector Jr. FC 1979 Effect of acetazolamide on bicarbonate reabsorption in the proximal tubule of the rat. Am J Physiol 237 (Renal, Fluid Electrolyte Physiol) F447-454

26. DuBose TD, Lucci MS, Crowther CA, Pucacco LR 1983 Effect of carbonic anhydrase inhibition on superficial and deep nephron bicarbonate reabsorption in the rat. J Clin Invest 71:55-65

27. Frommer JP, Laski ME, Werson DE, Kurtzman NA 1984 Intranephron heterogeneity for $\mathrm{CA}$-independent $\mathrm{HCO}_{3}^{-}$reabsorption in the rat. $\mathrm{J}$ Clin Invest 73:1034-1035

28. Schwartz JH, Rosen S, Steinmetz PR 1972 Carbonic anhydrase function and the epithelium organization of $\mathrm{H}^{+}$secretion in turtle urinary bladder. J Clin Invest 51:2653-2662

29. Gluck S, Kelly S, Al-Awqati Q 1982 The proton-translocating ATPase responsible for urinary acidification. J Biol Chem 257:9230-9233

30. Sly WS, Whyte MP, Sundaram V, Tashian RE, Hewett-Emmett D, Guibaud P, Vainsel M, Baluarte HJ, Gruskin A, Al-Mosawi M, Sakati N, Ohlsson A 1985 Carbonic anhydrase II deficiency in 12 families with the autosomal recessive syndrome of osteopetrosis with renal tubular acidosis and cerebral calcification. N Engl J Med 313:139-145 